\title{
KUALITAS PELAYANAN PEGAWAI KELURAHAN MENTENG KOTA PALANGKA RAYA DALAM PENERBITAN SURAT KETERANGAN TANAH (SKT)
}

\author{
Oleh: IRMA DAMAYANTI BR PADANG
}

\begin{abstract}
ABSTRAK
Dalam melaksanakan pelayanan yang baik, Kantor Kelurahan Menteng Kota Palangka Raya perlu memperhatikan kualitas pelayanan yang diberikan melalui Transparansi, akuntabilitas, kondisional, partisipatif, kesamaanhak, dan keseimbangan hak dan kewajiban. Hal ini bertujuan untuk meningkatkan yang diinginkan oleh masyarakat itu sendiri. Kantor Kelurahan Menteng Kota Palangka Raya adalah salah satu pelayanan yang bersinggungan langsung dengan masyarakat, tentu saja harus ada upaya-upaya yang kongkrit dari pihak Kelurahan Menteng Kota Palangka Raya untuk meningkatkan layanan demi kenyamanan dan kepuasan seluruh masyarakat selaku menerima pelayanan dari pegawai.

Metode penelitian yang digunakan adalah metode kualitatif deskriptif. Dimana metode ini digunakan untuk mengetahui kualitas pelayanan pegawai yang diberikan oleh Kantor Kelurahan Menteng Kota Palangka Raya, subjek peneliti dari penelitian ini adalah Seksi Pemerintahan, dan masyarakat sekitar di Kelurahan Menteng Kota Palangka Raya yang pernah mengurus Surat Keterangan Tanah di instansi tersebut. Sedangkan untuk teknik pengumpulan data dilakukan melalui observasi, wawancara, dan dokumentasi.

Kesimpulan yang diperoleh dari penelitian ini menunjukkan bahwa kualitas pelayanan Kantor Kelurahan Menteng Kota Palangka Raya masih kurang maksimal. Hal ini dapat dilihat masih ada keluhan masyarakat terkait pelayanan yang diberikan.Kurangnya tanggungjawab dalam pelayanan, adanya diskriminasi antara masyarakat yang mengurus SKT dan adanya kendala-kendala yang dihadapi masyarakat, dan tidak ada kotak saran diKelurahan Menteng Kota Palangka Raya untuk menampung aspirasi masyarakat.
\end{abstract}

\section{Kata kunci: Kualitas Pelayanan, Surat Keterangan Tanah, Organisasi Publik}

\section{PENDAHULUAN}

Berdasarkan keputusan Menteri PAN nomor 26/KEP/M.PAN/6/2004 tentang pedoman umum penyelenggaraan pelayanan publik, Maksud ditetapkannya petunjuk teknis ini adalah sebagai acuan bagi seluruh penyelenggara pelayanan publik untuk meningkatkan kualitas pelayanan, sementara tujuan ditetapkannya teknis ini adalah untuk memberikan kejelasan bagi seluruh penyelenggara pelayanan publik agar sesuai dengan tuntutan dan harapan masyarakat, penyelenggara pelayanan publik yang dilaksanakan oleh aparatur pemerintah dalam berbagai sektor pelayanan, terutama yang menyangkut pemenuhan hak sipil dan kebutuhan dasar masyarakat, kinerjanya masih jauh dari yang diharapkan, mekanisme kerja pelayanan yang berbelit-belit, tidak transparan, kurang informasi, 
dan terbatasnya fasilitas, sarana dan prasarana sehingga tidak menjamin kepastian (hukum, waktu, dan biaya). Buruknya kinerja pelayanan publik ini antara lain dikarenakan belum terlaksananya transparansi dan akuntabilitas dalam penyelenggara pelayanan publik. Oleh karena itu pelayanan publik harus dilaksanakan secara transparansi dan akuntabel oleh setiap unit pelayanan instansi pemerintah karena kualitas kinerja birokrasi memiliki implikasi yang luas dalam mencapai kesejahteraan masyarakat.

Salah satu instansi penyedia pelayanan di Kota Palangka Raya adalah Kelurahan Menteng yang dalam hal ini sebagai pelaksana pelayanan publik yang langsung bersinggungan dengan masyarakat, diharapkan mampu memberikan pelayanan yang baik. Kelurahan sebagai tingkat paling rendah dalam struktur pemerintahan, harus mampu memberikan pelayanan prima kepada masyarakat dan mampu memperlihatkan kinerja yang baik. Namun di lapangan sering sekali di jumpai keluhan masyarakat terhadap pelayanan yang di berikan oleh aparatur pemerintah di kelurahan, kurang nya keramahan pegawai juga menyebabkan masyarakat kurang dilayani dengan baik, pelayanan yang diberikan oleh kelurahan kepada masyarakat adalah "Surat keterangan tidak mampu, surat keterangan usaha, kartu keluaraga (KK), surat keterangan tanah (SKT), dan lain-lain. Dari pelayanan yang di berikan oleh kelurahan tersebut, masalah pembuatan Surat Keterangan Tanah sering menjadi keluhan masyarakat, misalnya kurang transparansinya administrasi yang terkait dengan biaya dan batas waktu penyelesaian surat keterangan tanah tersebut dan keluhan yang paling berat di hadapi masyarakat atau permasalahannya bagian letak patok batas tanah, masalah pengakuan tanah, Penyelenggara pelayanan publik yang buruk diIndonesia selama ini telah menjadi rahasia umum bagi setiap masyarakat sebagai penerima pelayanan, ungkapan ini tidaklah berlebihan ketika melihat fakta bahwa hak sipil warga sering dilanggar dalam proses urusan masyarakat. seperti masyarakat mau mengurus Surat Keterangan Tanah (SKT), pembuatan Surat Keterangan Tanah yang seharusnya mudah, dipersulit dengan banyaknya meja dan rangkaian prosedur yang harus dilalui. Keluhan-keluhan ini lah yang sering muncul dari masyarakat dalam penyelenggaraan pelayanan publik terutama dari rendahnya kualitas pelayanan pemerintah kepada masyarakat dalam melakukan pelayanan. Khusus pada Kantor Kelurahan Menteng Kota Palangka Raya, masyarakat masih mendapatkan pelayanan yang kurang maksimal di dalam menerima pelayanan pada saat mengurus yang mereka inginkan seperti waktu, biaya yang sudah di tentukan di saat pertemuan awal dengan masyarakat sehingga tingkat kepuasan masyarakat belum tercapai secara optimal. Ini dinyatakan oleh beberapa anggota masyarakat yang ada di sekitar kelurahan saat melakukan observasi awal. Aspek pelayanan merupakan bagian penting dalam strategi pengembangan tugas dan fungsi pemerintahan. Untuk itu perhatian terhadap kualitas pelayanan publik merupakan parameter dari keberhasilan birokrasi dalam pemuasan publik. Penyelenggaraan pelayanan publik yang berkualitas merupakan harapan yang didambakan masyarakat dengan anggapan hal tersebut merupakan hak yang harus di peroleh nya yang secara khusus dilaksanakan di Kelurahan Menteng Kota Palangka Raya. Hal ini tentu saja membuat masyarakat kurang simpati dan kurang percaya atas kinerja para pegawai kelurahan. 
Dari uraian latar belakang di atas, maka dapat dirumuskan permasalahan yang akan diteliti oleh peneliti adalah Bagaimana kualitas pelayanan Pegawai Kelurahan Menteng Kota Palangka Raya?

Adapun tujuan yang ingin dicapai dalam penelitian ini untuk mendeskripsikan dan menganalisa Kualitas Pelayanan Pegawai Kelurahan Menteng Kota Palangka Raya.

\section{TINJAUAN PUSTAKA}

\section{Definisi kualitas}

Kata kualitas mengandung banyak pengertian menurut kamus bahasa Indonesia kualitas berarti tingkat baik buruknya sesuatu, konsep kualitas pelayanan dapat dipahami melalui perilaku konsumen yaitu suatu perilaku yang dimainkan oleh konsumen dalam mencari, membeli, menggunakan, dan mengevaluasi suatu produk maupun pelayanan yang diharapan dapat memuaskan kebutuhan mereka

\section{Definisi pelayanan}

Salah satu perwujudan dari tugas dan fungsi negara adalah dengan menyediakan pelayanan publik bagi seluruh masyarakat Indonesia.Definisi pelayanan menurut (Winarsih dan Ratminto, 2006:105), adalah pelayanan administrasi pemerintahan yang sering dipergunakan sebagai konsepsi pelayanan perizinan dan pelayanan umum. Pelayanan perizinan adalah pelayanan yang memenuhi kebutuhan masyarakat, juga melaksanakan ketentuan peraturan perundang-undangan yang bentuk produk pelayanannya izin dan warkat. Dan menurut (warella, 2004:72) pelayanan adalah suatu perbuatan suatu kinerja, suatu usaha, jadi menunjukkan pentingnya penerima jasa pelayanan terlibat secara aktif di dalam produksi atau penyampaian proses pelayanan itu sendiri. Dan menurut Sianipar menyatakan bahwa untuk menjadi seorang yang professional dalam memberikan pelayanan, aparatur negara harus memiliki kemampuan dan pengetahuan tentang bidang tugas masing-masing.

\section{Kualitas pelayanan}

Menurut Ibrahim (2008:22), kualitas pelayanan publik merupakan suatu kondisi dinamis yang berhubungan dengan produk, jasa, manusia, proses dan lingkungan dimana penilaian kualitas nya ditentukan pada saat terjadinya pemberian pelayanan publik tersebut.

\section{Transparansi}

Pengertian Transparansi menurut Sinambela dkk, (2006:6) adalah "bersifat terbuka, mudah dan dapat diakses oleh semua pihak yang memerlukan dan disediakan secara memadai serta mudah dimengerti".Menurut (Krina, 2003:13) mengatakan transparansi adalah "sebagai prinsip yang menjamin akses atau kebebasan bagi setiap oranguntuk memperolehinformasi tentang penyelenggaraanpemerintahan, yakni informasi tentang kebijakan proses pembuatan dan pelaksanaanya serta hasilhasil yang dicapai”. Menurut (Agus Dwiyanto,2006:80) mendefinisikan transparansi adalah "sebagai penyediaan informasi tentang pemerintahan bagi publik dan dijaminnya kemudahan didalam memperoleh informasi-informasi yang 
akurat dan memadai", Sedangkan menurut (Hari Sabarno,2007:38) transparansi merupakan "salah satu aspek mendasar bagi terwujudnya penyelenggaraan pemerintahan yang baik".

\begin{abstract}
Akuntabilitas
Pengertian Akuntabilitas menurut Sinambela dkk, (2006:6) adalah "dapat dipertanggungjawabkan sesuai dengan ketentuan peraturan perundangundangan",menurut Dadang Juliatara,(2005:11) akuntabilitas adalah"dapat dipertanggungjawabkan sesuai dengan ketentuan perundang-undangan".
\end{abstract}

\title{
Kondisional
}

Pengertian Kondisional menurut Sinambela dkk, (2006:6) adalah "sesuai dengan kondisi dan kemampuan pemberi dan penerima pelayanan dengan tetap berpegang pada prinsip efisien dan efektivitas". Dadang Juliantara, (2005:11) mengatakan bahwa kondisional adalah "sesuai kondisi dan kemampuan pemberi dan penerima pelayanan dengan tetap berpegang pada prinsip efektivitas dan efisiensi”.

\section{Partisipatif}

Pengertian Partisipatif menurutSinambela dkk, (2006:6) adalah "mendorong peran serta masyarakat dalam menyelenggarakan pelayanan publik dengan memerhatikan aspirasi, kebutuhan, dan harapan masyarakat". Dan Dadang Juliantara, (2005:11) partisipatif adalah "mendorong peran serta masyarakat dalam menyelenggarakan pelayanan publik dengan memerhatikan aspirasi, kebutuhan, dan harapan masyarakat"

\section{Kesamaan hak yaitu tidak deskriminatif}

Pengertian Kesamaan hak yaitu tidak diskriminatif menurut Sinambela dkk, (2006:6) adalah "dalam arti tidak membedakan suku, ras, agama,golongan, gender,dan status ekonomi”. Dan menurut (Dadang Juliantara, 2005:11) kesamaan hak yaitu tidak diskriminatif adalah "dalam arti tidak membedakan suku, ras, agama,golongan, gender,dan status ekonomi”.

\section{Keseimbangan hak dan kewajiban}

Pengertian Keseimbangan hak dan kewajiban menurut Sinambela dkk, (2006:6) adalah "pemberi dan penerima pelayanan publik harus memenuhi hak dan kewajiban masing-masing". Dan menurutDadang Juliantara,(2005:11) kesimbangan hak dan kewajiban adalah "pemberi dan penerima pelayanan publik harus memenuhi hak dan kewajiban masing-masing".

\section{METODE PENELITIAN}

\section{Pendekatan Penelitian}

Ditinjau dari penelitian yang dilakukan maka pendekatan penelitian yang digunakan oleh peneliti adalah penelitian kualitatif dimana pendekatan ini bertujuan untuk menggambarkan atau mendeskripsikan masalah-masalah yang ada pada obyek penelitian. Menurut (Sutopo, 2012:48) 'penelitian kualitatif lebih menekankan pada makna, lebih memfokuskan pada data dan kualitas dengan 
analisis kualitatifnya". Dengan kata lain penelitian kualitatif lebih mementingkan makna, tidak ditentukan oleh kuantitasnya tetapi lebih ditentukan oleh proses terjadinya dan cara memandang atau perspektifnya. Dalam penelitian ini peneliti berupaya mencaritahu realitas yang ditemui dilapangan dalam rangka mengetahui kualitas pelayanan di Kelurahan Menteng Kota Palangka Raya.

\title{
Analisis data
}

Pada dasarnya adalah proses perincian atau penyederhanaan data kedalam bentuk yang mudah dibaca dan diinterprestasikan. Miles dan Huberman (1984), mengemukakan bahwa aktivitas dalam analisis data kualitatif dilakukan secara interaktif dan berlangsung secara terus-menerus sampai tuntas, sehingga datanya sudah jenuh. Ukuran kejenuhan data ditandai dengan tidak diperolehnya data atau informasi baru. Aktifitas dalam analisis meliputi reduksi data(data reduction), penyajian data (data display), serta penarik kesimpulan dan verifikasi (conclusion drawing/verification).

\section{PEMBAHASAN}

\section{Transparansi}

Berdasarkan hasil penelitian dari wawancara, peneliti menilai bahwa transparansi dalam memberikan informasi sudah baik hal ini terlihat dari pernyataan masyarakat bahwainformasi itu memang didapatkan dari Kelurahan, namun perlu ditingkatkan lagi dalam penyampaian kepada masyarakat, seharusnya pegawai memberikan informasi secara langsung agar masyarakat mudah mengakses dan memahami setiap informasi yang diperoleh dari pegawai demi kelancaran dalam pemberi dan penerima pelayanan begitu juga penyelesaian pembuatan SKT tersebut.

\begin{abstract}
Akuntabilitas
Dari permasalahan yang terkait dengan pelayanan akuntabilitas, dalam meningkatkan kualitas pelayanan yang baik perlu dilakukan upaya-upaya yang strategis untuk memuaskan masyarakat dalam hal waktu dan biaya pengurusan SKT, alangkah baiknya jika biaya administrasi itu dipatokkan supaya pembayaran pengurusan SKT tersebut sama rata dan sebaiknya pegawai Kelurahan menyelesaikan SKT tersebut dalam waktu yang tidak lama agar masyarakat tidak terlalu lama menunggu.
\end{abstract}

\section{Kondisional}

Dari permasalahan yang ada peneliti menilai bahwa dalam melaksanakan kondisional kurang maksimal dan perlu adanya perbaikan dari pihak Kelurahan agar memperhatikan setiap informasi yang diberikan dan ketelitian dalam penafsiran informasi agar masyarakat bisa lebih mudah dan memahami apa saja yang harus mereka lakukan dalam proses pelayanan. Dan kepada masyarakat dihimbau juga agar tanah mereka dipelihara dengan baik agar tidak terjadinya sengketa atau tumpang tindih tanah 


\section{Partisipatif}

Dari beberapa permasalahan terkait dengan pelayanan yang pastisipatif dari segi masyarakat yang harus aktif serta kotak saran untuk mendengarkan aspirasi masyarakat dalam memenuhi pelayanan yang pastisipatif tidak ada, peneliti menilai bahwa perlu adanya perbaikan dari Kelurahan Menteng Kota Palangka Raya, baik dalam memberikan informasi kepada masyarakat begitu juga kotak saran yang harus disediakan. Ini bertujuan untuk meningkatkan kualitas pelayanan yang masi kurang menjadi lebih baik lagi untuk masyarakat, karena menurut peneliti kotak saran itu sangat penting karena itu adalah salah satu bentuk aspirasi masyarakat, tempat masyarakat mencurahkan segala unek-unek mereka, jadi dengan begitu pegawai Kelurahan juga bisa meningkatkan kualitas pelayanan dengan melihat keluhan masyarakat melalui kotak saran.

\section{Kesamaan hak}

Berdasarkan penelitian dilapangan bahwa masyarakat mengeluh tentang adanya perbedaan didalam pelayanan,perbedaan itu sering terjadi didalam penyelesaian dan biaya administrasi dari pihak Kelurahan Menteng Kota Palangka Raya dalam penerbitan SKT tersebut, masyarakat mengatakan jika masyarakat itu ada kedekatan dengan pihak Kelurahan maka pengurusan mereka cepat diselesaikan.

Melihat permasalahan diatas peneliti menilai bahwa keseimbangan hak belum baik. Dan perlu adanya peningkatan, sebaiknya pegawai tidak pernah membedakan antara masyarakat yang mengurus SKT, karena mereka mempuanyai hak yang sama dalam menerima layanan dan juga seharusnya tidak ada keberpihakan antara satu dengan yang lainnya karena kepuasan masyarakat adalah yang harus diutamakan.

\section{Keseimbangan hak dan kewajiban}

Berdasarkan pernyataan diatas peneliti menilai bahwa dalam melaksanakan keseimbangan hak dan kewajiban sudah baik. Hal ini juga terlihat dari pernyataan masyarakat, bahwa hak dalam pelayanan sudah didapatkan walaupun belum memuaskan, walaupun begitu peneliti juga menilai bahwa masih ada yang harus ditingkatkan dari Kelurahan yakni dari proses pelayanan keseimbangan hak dan kewajiban pegawai yang dapat ditingkatkan bagian kepastian waktu penyelesaian dan tidak ada diskriminasi atau keberpihakan antara masyarakat.

\section{KESIMPULAN}

Dari hasil pembahasan di bab sebelumnya maka peneliti menyimpulkan bahwa kualitas pelayanan publik yang berada di Kantor Kelurahan Menteng Kota Palangka Raya bisa dikatakan masih kurang maksimal, dikarenakan masih adanya keluhan dari masyarakat terhadap pelayanan pegawai yang diberikan oleh pihak Kelurahan Menteng Kota Palangka Raya. Selain dari keluhan masyarakat, dapat dilihat dari aturan atau prosedur-prosedur yang dimiliki Kantor Kelurahan Menteng Kota Palangka Raya yang tidak begitu jelas dan tidak tertulis jadi kalau misalnya masyarakat ingin mengurus Surat Keterangan Tanah tidak ada aturan atau prosedur yang bisa dibaca tetapi pihak Kelurahan hanya memberikan sebuah formulir yang harus diisi dan kadang informasi yang dibutuhkan masyarakat juga tidak semua dijelaskan secara langsung, tetapi menempelkan dipapan pengumuman yang ada di 
Kelurahan Menteng Kota Palangka Raya. Dari segi transparansi yang ada diKelurahan Menteng sudah baik, masyarakat sudah mendapatkan setiap informasi yang mereka butuhkan walaupun masih belum memuaskan, dan dari segi akuntabilitas pihak Kantor Kelurahan Menteng Kota Palangka Raya masih kurang dalam pengurusan Surat keterangan Tanah (SKT), karena masih ada kendala dalam waktu penyelesaian, biaya administrasi yang tidak ada pematokan dan penundaan penyelesaian SKT dikarenakan yang berwenang tidak ada dikantor. Selain itu pelayanan yang kondisional juga kurang maksimal pada Kantor Kelurahan Menteng Kota Palangka Raya, karena masih ada keluhan masyarakat dalam menerima informasi kadang ada kesalahan dari pegawai hal ini lah yang menjadi kendala dimasyarakat dalam mengakses dan memahami informasi yang didapat dari Kelurahan. Dan pelayanan yang partisipatif didalam melayani masyarakat sudah cukup aktif walaupun pegawai Kelurahan masih mengharapakan masyarakat agar lebih pro aktif lagi dalam pengaksesan informasi, yang menjadi masalah juga disini adalah tidak adanya kotak saran untuk mendengar aspirasi atau keluhan masyarakat demi meningkatkan kualitas pelayanan. Dan dari segi pelayanan kesamaan hak diKelurahan Menteng Kota Palangka Raya masih belum baik, karena masih ada diskriminasi antara masyarakat yang mau mengurus Surat Keterangan Tanah baik dalama dministarasi maupun dari waktu penyelesaian dan masyarakat juga berfikir bahwa adanya keberpihakan. Dan pelayanan keseimbangan hak dan kewajiban yang ada di Kantor Kelurahan Menteng Kota Palangka Raya sudah baik masyarakat sudah mendapatkan hak mereka dari pegawai Kelurahan Menteng Kota Palangka Raya walaupun belum memuaskan.

Adapun cara yang bisa dilakukan Dalam meningkatkan mutu pelayanan yang berkualitas, yaitu melalui aturan dan prosedur yang jelas dan tertulis dan mudah dimengerti, persyaratan yang mudah untuk dipenuhi, tidak adanya diskriminasi antara masyarakat dalam pelayanan, waktu penyelesaian yang jelas dan pematokan biaya agar adapun pembayaran administrasi dalam pengurusan SKT tersebut, pembayaran itu sama rata antara masyarakat satu dengan yang lainnya, jadi masyarakat tidak berfikir bahwa adanya keberpihakan antara pegawai dengan masyarakat. Dan menjelaskan secara detail mengenai informasi-informasi yang dibutuhkan oleh masyarakat agar masyarakat bisa mudah memahami dan menyelesaiakan segala permasalahan yang ada di obyek tanah mereka dan disaat terjalinnya pelayanan dikantor dengan begitu waktu penyelesaian dengan cepat akan didapatkan oleh masyarakat.

\section{SARAN}

Adapun saran yang dapat diberikan oleh peneliti antara lain:

1. Hal yang paling penting ditingkatkan oleh Kelurahan Menteng Kota Palangka Raya dalam meningkatkan Kualitas pelayanan disini adalah: Bagian Akuntabilitas, Kesamaan hak, dan kondisional.

2. Dalam menyelenggarakan pelayanan penerbitan Surat Keterangan Tanah yang berkualitas tidak hanya dibutuhakan keramahan tetapi juga dipengaruhi oleh tanggungjawab saat melaksanakan pelayanan tersebut, tanggungjawab yang dimaksud disini adalah memberikan pelayanan yang merata kepada masyarakat, tidak adanya perbedaan pelayanan yang satu 
dengan lainnya karena tugas pegawai itu memberikan tanggungjawab dalam melayani secara seksama agar masyarakat mendapatkan kepuasan dan tidak beranggapan kalau adanya diskriminasi didalam masa pelayanan.

3. Ketepatan waktu sebagai kewajiban yang harus dibenahi saat melakukan pelayanan kepada masyarakat dalam menerbitkan SKT, karena masyarakat tidak akan puas jika keterlambatan penerbitan itu dikarenakan kendala yang kecil saja tetapi tidak bisa diproses kebutuhan mereka, misalnya tidak ada petugas yang berwenang dikantor jadi masyarakat harus menunggu atau menitipkan berkas, hal ini lah yang harus diperbaiki oleh pegawai demi meningkatkan kualitas pelayanan kepada masyarakat dan kalau bisa masalah biaya itu harus diperjelas dan dipatokkan supaya tidak ada perbedaan pembayaran antara masyarakat dalam mengurus Surat Keterangan Tanah.

4. Pihak Kelurahan Menteng Kota Palangka Raya juga harus menyediakan kotak saran untuk mendengarkan aspirasi masyarakat, kadang-kadang masyarakat tidak bisa langsung mengatakan keluhan mereka kepada pihak Kelurahan, Tetapi dengan adanya kotak saran mungkin bisa membantu masyarakat dalam mengeluarkan keluhan atau aspirasi mereka lewat kotak saran tersebut jia pelayanan kurang memuaskan.

5. Dan bagian kondisional perlu ditingkatkan oleh pegawai Kelurahan Menteng Kota Palangka Raya dibagian penyampaian informasi dan penafsiran imformasi yang disampaikan kepada masyarakat karena ini lah salah satu jadi kendala dalam masyarakat dan kehadiran pegawai dikantor sebaiknya ditingkatkan juga agar masyarakat tidak harus menitip berkas dikarenakan pegawai yang bersangkutan tidak hadir dikantor, hal ini juga pegawai harus lebih bertanggungjawab lagi dalam menjalankan wewenangnya dalam memberikan pelayanan yang baik.

\section{DAFTAR PUSTAKA}

Barata, Atep Adya.2004. Dasar-dasar Pelayanan Prima. Jakarta: Elex Media Komputindo.

Basuki, Heru.2006. Penelitian kualitatif untuk ilmu-ilmu kemanusiaan dan budaya. Jakarta: Penerbit Gunadarma.

Hardiyansyah. 2011. Kualitas pelayanan publik konsep, indikator, dan implementasi. Yogyakarta: Gaya Media

Lion eddy, Bunu Helmith y.2013. Metodologi penelitian kualitatif. Surabaya: Jenggala Pustaka Utama

Milles, Martthew B, Michael Huberman.1992. Analisis data kualitatif.Buku tentang metode-metode baru, terjemahanTjetjep Rohendi Rohidi. Jakarta: UI-press

Moenir. 2014. Pengertian pelayanan. Jakarta: Rineka Cipta. 
Mukarom, zaenaldanlaksana, Muhibudin Wijaya.2015.Manajemen pelayanan publik. Bandung: CV Pustaka Setia.

Pasalog Harbani.2011. Teori administrasi publik. Bandung: Alfabeta.

Peraturan perundng-undanganKeputusan Menteri Pendayagunaan Aparatur Negara No 63/KEP/M.PAN/7/2003 tentang pedoman umum pelayanan publik

PeraturanPemerintahNomor 24 Tahun 1997 tentang Pendaftaran Tanah.

Sinambela, Lijan poltak dkk. 2006. Reformasi pelayanan publik: Teori kebijakan, dan implementasi. Jakarta: Bumi Aksara.

Surat keterangan tanah dari kelurahan (online pada tanggal 1 September 2016 http://cara-buat-surat.blogspot.co.id/2016/02/surat-keterangan-tanah-darikelurahan.html

Syukuri, Agus Fanar.2009. Standar pelayanan publik. Bantul: Kreasi Wacana 